\title{
Chemodiversity of Calophyllum inophyllum L. oil bioactive components related to their specific geographical distribution in the South Pacific region
}

\author{
Joape Ginigini ${ }^{1}$, Gaël J Lecellier ${ }^{\text {Corresp., } 2}$, Maël Nicolas ${ }^{3}$, Mohammed Nour ${ }^{3}$, Edouard Hnawia ${ }^{3}$, Nicolas Lebouvier ${ }^{3}$, \\ Gaëtan Herbette $^{4}$, Peter Lockhart ${ }^{5}$, Phila Raharivelomanana ${ }^{6}$ \\ 1 Pacific natural products research centre, Institute of Applied Sciences, University of the South Pacific, Suva, Fiji \\ 2 Départment de Biologie, Université de Versailles Saint-Quentin-en-Yvelines, Versailles, France \\ 3 ISEA EA7484, University of Caledonia, Noumea, New Caledonia \\ ${ }^{4}$ Spectropole, Campus de St Jérôme, Aix-Marseille Univ, CNRS, Centrale Marseille, FSCM, Marseille, France \\ 5 School of Fundamental Sciences, Massey University, Palmerston North, New Zealand \\ 6 EIO UMR241, Université de la Polynésie française, Faa'a, Tahiti, French Polynesia \\ Corresponding Author: Gaël J Lecellier \\ Email address: gael.lecellier@uvsq.fr
}

Background. Different parts of the tree Calophyllum inophyllum L. (nuts, leaves, roots, bark, fruits, nut oil and resin) are used as traditional medicines and cosmetics in most of the Pacific Islands. The oil efficiency as a natural cure and in traditional cosmetics has been largely described throughout the South Pacific, which led us to investigate $C$. inophyllum's chemical and genetic diversity. A correlative study of the nut resin and leaf DNA from three distinct archipelagos in the South Pacific was carried out in order to identify diversity patterns in $C$. inophyllum across the South Pacific.

Methods. C. inophyllum plants were sampled from French Polynesia, New Caledonia and Fiji. We extracted tamanu oil (nut oil) resin for chemo-diversity studies and sampled leaf tissues for genetic studies. We applied an analysis method designed for small quantities (at a microscale level), and used HPLC to establish the chemo-diversity of tamanu oil resin. In-house standards were co-eluted for qualitative determination. Genetic diversity was assessed using chloroplast barcoding markers (the Acetyl-CoA carboxylase (accD) gene and the psaA-ycf3 intergenicspacer region).

Results. Our HPLC analysis revealed 11 previously known tamanu oil constituents, with variability among plant samples. We also isolated and characterized two new neoflavonoids from tamanu oil resin namely, tamanolide E1 and E2 which are diastereoisomers. Although genetic analysis revealed low genetic variation, our multivariate analysis (PCA) of the tamanu oil resin chemical profiles revealed differentiation among geographic regions.

Conclusion. We showed here that chromatographic analysis using formalized in-house standards of oil resin compounds for co-elution studies against oil resin samples could identify patterns of variation among samples of $C$. inophyllum, and discriminate samples from different geographical origins. 
1 Chemodiversity of Calophyllum inophyllum L. oil bioactive components related to their 2 specific geographical distribution in the South Pacific region

3 Joape Ginigini ${ }^{1}$, Gaël J Lecellier ${ }^{2}$, Maël Nicolas ${ }^{3}$, Mohammed Nour ${ }^{3}$, Edouard Hnawia ${ }^{3}$, Nicolas

4 Lebouvier $^{3}$, Gaëtan Herbette ${ }^{4}$, Peter Lockhart ${ }^{5}$ and Phila Raharivelomanana ${ }^{6}$

5

6 1. Pacific natural products research centre, Institute of Applied Sciences, University of the

$7 \quad$ South Pacific, Suva, Fiji

8 2. Université de Versailles Saint-Quentin-en-Yvelines, Département de Biologie, France

9 3. ISEA EA 7484 University of Caledonia, New Caledonia

4. Aix-Marseille Univ, CNRS, Centrale Marseille, FSCM, Spectropole, Campus de St Jérôme, France

5. Massey University, Palmerston North, School of Fundamental Sciences, New Zealand

6. Université de la Polynésie Française, UMR 241 EIO, Tahiti, French Polynesia

16 Corresponding author:

17 Gaël Lecellier

18 Email address: gael.lecellier@uvsq.fr 


\section{ABSTRACT}

Background. Different parts of the tree Calophyllum inophyllum L. (nuts, leaves, roots, bark, fruits, nut oil and resin) are used as traditional medicines and cosmetics in most of the Pacific Islands. The oil efficiency as a natural cure and in traditional cosmetics has been largely described throughout the South Pacific, which led us to investigate $C$. inophyllum's chemical and genetic diversity. A correlative study of the nut resin and leaf DNA from three distinct archipelagos in the South Pacific was carried out in order to identify diversity patterns in $C$. inophyllum across the South Pacific. Methods. C. inophyllum plants were sampled from French Polynesia, New Caledonia and Fiji. We extracted tamanu oil (nut oil) resin for chemo-diversity studies and sampled leaf tissues for genetic studies. We applied an analysis method designed for small quantities (at a microscale level), and used HPLC to establish the chemo-diversity of tamanu oil resin. In-house standards were co-eluted for qualitative determination. Genetic diversity was assessed using chloroplast barcoding markers (the Acetyl-CoA carboxylase (accD) gene and the psaA-ycf3 intergenicspacer region). Results. Our HPLC analysis revealed 11 previously known tamanu oil constituents, with variability among plant samples. We also isolated and characterized two new neoflavonoids from tamanu oil resin namely, tamanolide E1 and E2 which are diastereoisomers. Although genetic analysis revealed low genetic variation, our multivariate analysis (PCA) of the tamanu oil resin chemical profiles revealed differentiation among geographic regions. Conclusion. We showed here that chromatographic analysis using formalized in-house standards of oil resin compounds for co-elution studies against oil resin samples could identify patterns of variation among samples of $C$. inophyllum, and discriminate samples from different geographical origins.

\section{INTRODUCTION}

Chemical and medicinal properties of Alexandrian laurel (Calophyllum inophyllum), commonly known as beach mahogany, have been extensively studied throughout the world and even more in the Asia-Pacific region (Léguillier et al, 2015; Pawar et al., 2011; Patil et al., 1993). The plant has a myriad of medicinal uses, most of them involving topical applications. Recent studies such as Léguiller et al. (2015) and Ansel et al. (2016) have focused more attention on the cosmetic aspects of the plant in the Pacific region. Other common names for the plant in some Pacific island countries are dilo (Fiji), fetau (Samoa), tamanou de bord de mer (New Caledonia) and 
51 tamanu in the Cook Islands and French Polynesia. (Friday and Okano, 2006). Historically, before

52 the conversion of Polynesians to Christianity, the tamanu trees were considered as sacred. They were planted inside the royal Marae (sacred areas) (Dweck and Meadow, 2002). Calophyllum inophyllum belongs to the flowering plant family Calophyllaceae (APG, 2009; Prabakaran and Brito, 2012) and is native to the Indo-Pacific region (Africa, India, South East Asia, Australia and the Pacific islands). It grows to a height of $8-15 \mathrm{~m}$ and has a large canopy. The wood is widely used for making cabinet and other furniture, for carving, and for boat and canoe building. Furthermore, different parts of the plant have been used in traditional medicine and as excellent raw material for cosmetics (Dweck and Meadows, 2002). For instance, the nut oil has been used for medicine against skin infections, as a scar remover as well as for other cosmetic uses (Friday and Okano, 2006). In Fiji, the oil is used to cure arthritis and joint pain, as an eye wash for conjunctivitis (Cambie and Ash, 1994) and also to prevent infantile rash. The resin mixed with strips of bark and leaves is used as a treatment for sore eyes. The green fruit is used against tuberculosis (Cambie and Ash, 1994). In some islands of Polynesia, the oil has been used as an alternative for candle nut oil in lamps and also massaged into hair and used as a common topical application for skin diseases and burns (Prabakaran and Brito, 2012). A number of studies have revealed interesting oil biological activities such as antibacterial (Yimdjo et al, 2004), antifungal (Saravan et al., 2011), anti-inflammatory against skin infections (Bhalla et al., 1980). Most recently it has proven useful for wound healing (Léguiller et al., 2015). Such is the uniqueness of its properties that "tamanu oil" has been recognised as an active cosmetic ingredient and recorded as $C$. inophyllum seed oil by the International Nomenclature of Cosmetic Ingredients (INCI) (Assouvie, 2013; Ansel et al., 2015).

The bioactive components (belonging to neoflavonoid, xanthone and triterpene secondary metabolite groups) in this plant are highly rich and recognised as having medicinal properties as shown in Table 1. The composition of the main neoflavonoid compounds in the oil are as follows: calophyllolide, inophyllums (C, D, E and P), tamanolides D and P, calanolide Gut 70, and finally the calanolides A, B and D (Laure, 2005; Leu et.al., 2009; Assouvie, 2013). Also of great interest is the anti-HIV efficiency of pyranocoumarins from the Calophyllum genus (Wang et al., 2006). Recent studies have also examined their use in cicatrization, and as an anti-aging agent (Léguillier et al., 2015; Ansel et al., 2016). The calanolide A compound, a minor constituent of $C$. inophyllum resin extract (Ansel et.al., 2016) has also attracted recent interest 
82 because it is the only natural product that has progressed into human clinical trials with positive results against HIV-1 (Wang et al., 2006).

The chemical composition analysis of $C$. inophyllum leaves from various sites in French Polynesia and that of fruits originating from various sites in India has revealed regional differentiation (Laure et al., 2005, Pawar et al., 2011) between C. inophyllum plants found inland and closer to the coast. In order to evaluate the chemical qualities of the different tamanu oils of the South Pacific, phytochemical analyses are therefore necessary. Given that secondary metabolites play a role in the adaptation of plants to biotic and abiotic factors, it would be interesting to know if, as revealed by Pawar et al., 2011, abiotic factors such as those associated with the geography of harvesting sites have an influence on the chemical profile of tamanu oil. In addition to the general question of regional influence on the chemical profiles of tamanu oil, we were also interested in whether dipyranocoumrins and more particularly inophyllums can be used, as described by Pawar et al., 2011, as chemotaxonomic markers for the identification of $C$. inophyllum from various geographical areas of the South Pacific. To address these questions, from three South Pacific countries (French Polynesia, New-Caledonia and Fiji) shown on Oceania's map in Fig. 1. we characterized genetic diversity together with the phytochemical diversity, following a polyphasic approach, as already applied to some microbial research. Polyphasic taxonomy is a consensus method of taxonomy developed to incorporate phenotypic, genotypic and phylogenetic data for micro-organisms (Vandamme et al., 1996). A simplified version of this method for plant research, utilising only genotype and phenotype variation for elucidation of diversity has been successfully used by Pawar et al. (2011), Lynch et al. (2016), and $\mathrm{Hu}$ et al., (2007). As in these previous studies, the present study is aimed at giving more insight into the diversity of the C. inophyllum plant in Fiji, French Polynesia and New Caledonia by using genetic data from barcoding universal gene markers in accD and psaA-ycf3. We expect that by studying the genetic variation and corresponding HPLC chemical profiles (phenotypic information) for each sample, we can gain new insights that could help explain current diversity patterns of this plant. Our approach differs from Pawar et al. (2011) in that it does not utilise simple sequence repeat markers. Instead, we used sequence data from two chloroplast regions that have been employed for barcoding: the accD gene and the psaA-ycf3 intergenic spacer region. The plastid accD gene, which encodes for the $\beta$-carboxyl transferase subunit of acetyl coenzyme A carboxylase, is present in the plastids of most flowering plants, including non- 
113 photosynthetic parasitic plants and is involved in fatty acid biosynthesis. Associated with a fast

114 evolving genome region in some evolutionary lineages, it has been used in barcoding experiment

115 analyses for Magnoliophyta (Lahaye et al., 2007), Mesangiospermae (Lam et al., 2016) and

116 Fabids (Xi et al, 2012). Studies with Chlamydomonas reinhardtii and higher plants have shown

117 that ycf3 is required for the assembly of the Photosystem 1 complex (Boudreau et al., 1997; Ruf

118 et al., 1997).

119

120

\section{MATERIALS AND METHODS}

121

\section{Sample collection}

123 Tamanu nuts were collected during the fruit flushing season from June to August and even 124 collected late in December. In New Caledonia, tamanu nuts were collected under the scientific 125 authorization of the South Province N²050-2014. In Fiji, all samples were collected along 126 roadsides at each collection site. At each location, a replicate sampling plan was applied as 127 observed in the geodata (Table 2). A total of two leaf samples were collected at each tree 128 together with 3-5 nuts. From the leaf composite, one leaf was placed in a zip lock bag as a 129 voucher and two leaf samples were stored at $-80^{\circ} \mathrm{C}$ or immediately placed into DNA/RNA 130 Shield $^{\mathrm{TM}}$ (zymo research) solution for DNA extraction. The nuts were placed in polyethylene 131 trays and aired to remove moisture for two weeks before they were placed into a solar drier and 132 dried for six to eight weeks. In total, there were twenty two sampled sites and a total of eighty 133 five trees sampled from the three major collections in Fiji, French Polynesia and New Caledonia. 134 Note that due to the nature of collections being conducted in isolated locations from both French 135 Polynesia and New Caledonia, limited amount of material was collected and thus vouchers 136 specimens could not be deposited for these two research groups. Only the samples collected in 137 Fiji had vouchers deposited at the South Pacific Regional Herbarium (Table S1).

\section{Microscale Extraction, Purification and HPLC analysis}

140 From each of the 85 collected trees, a set of 3-5 nuts weighing 7-10 g were picked up and 141 subjected to small scale cold extraction consisting of maceration and nut grinding in a cheese 142 cloth followed by crushing in a mortar and pestle to allow oil expression through the cloth. 143 Samples were washed with EtOAc (provided by VWR Chemicals) and sonicated for 5 mins to 
144 extract all nut components. These were dried in vacuo to yield a crude extract containing

145 classical fatty acids components and de-fatted compounds. This last crude extract (oil) was then 146 partitioned with EtOH (provided by Fisher chemical) at a 1:1 ratio v/v to extract only EtOH

147 soluble non fatty compounds. The EtOH layer was removed and dried under vacuum yielding a

148 resinous extract (called resin) containing neoflavonoids compounds, which will be submitted to 149 further chemical analysis. Any remaining oil was de-fatted twice with $40 \mathrm{~mL}$ hexane in total.

150 Resinous extracts were dissolved in EtOAc: =cyclohexane (provided by VWR Chemicals) at a

$1511: 1 \mathrm{ratio} \mathrm{v} / \mathrm{v}$ at a concentration of $10 \mathrm{mg} / \mathrm{mL}$ for final injection. Chromatographic analyses were 152 performed using an Agilent 1100 series gradient HPLC fitted with a UV/DAD system. The 153 HPLC column used was an Interchrome Modula-Cart QS Uptisphere $5 \mu \mathrm{m}$ Si column, and the 154 data were viewed on Agilent Chemstation software. Optimized step gradient elution was applied 155 utilising Cyclohexane (HPLC grade from Fisher chemical) and EtOAc (HPLC grade from Fisher 156 chemical) as solvent and the analytical conditions were as follows: flow rate $1 \mathrm{~mL} / \mathrm{min}$, pressure 1572500 psi max, injection volume of $4 \mu \mathrm{L}$. The solvent system gradient conditions are shown in 158 Table S2 in the supporting information.

159 HPLC analysis of the samples from all three locations (Fiji: RawDataS1, New Caledonia:

160 RawDataS2 and French Polynesia: RawDataS3) involved numerous trials to obtain the 161 maximum amount of compounds in the shortest runtime. On completion of the analysis, eighty 162 resin samples were chosen from the total of eighty five samples and five were discarded due to 163 poor alignment and high signal to noise. Two more samples were discarded due to poor 164 alignment. In total, seventy eight samples were analysed by HPLC. Sample chromatogram 165 profiles were recorded at $280 \mathrm{~nm}$, wavelength at which most peaks were observed in the 166 optimized analytical conditions for neoflavonoid standards. The removal of noise, redefinition 167 and alignment of all data was necessary to identify and assign each sample peak before 168 comparing these to standard compounds which were isolated and identified in previous studies 169 (Leu et al., 2009; Leu, 2009; Laure, 2005 and Laure et al., 2008). Background fitting and 170 identification of major peaks of the raw HPLC data were performed using the R package align 171 DE v2.0.1. Chromatograms were aligned using a procedure in Scilab version 5.5.1 (Scilab 172 Enterprises, 2012) derived from chromaligner (Wang et al., 2010). 
174 Purification of known compounds from commercial tamanu oil resin and isolation of new 175 compounds

176 A batch of oil resin extract (157 g) from commercial tamanu oil (provided by "Laboratoire de 177 Cosmétologie du Pacifique Sud" manufacture) from French Polynesia was first partitioned with 178 EtOH (provided by Fisher chemical) and an aqueous alkaline solution of $\mathrm{Na}_{2} \mathrm{CO}_{3}$ (from VWR 179 chemicals) $(10 \%, \mathrm{v} / \mathrm{v})$. Its organic fraction was washed with distilled water and then dried with $180 \mathrm{MgSO}_{4}$ (provided by VWR chemicals) to give a neutral fraction (53 g) after solvent evaporation. 181 This fraction was submitted to flash liquid chromatography on an open column with a silica gel 182 (240-300 mesh) using a stepwise gradient from cyclohexane (provided by VWR chemicals) to 183 EtOAc (provided by VWR chemicals), yielding 12 fractions. Fractions having similar $\mathrm{R}_{\mathrm{f}}$ values 184 on silica gel TLC (cyclohexane-acetone, both provided by VWR chemicals, 60:40, v/v) were 185 combined. Fractions 7, 9 and 11 were submitted to repeated preparative HPLC using a Varian 186 Dynamax Si column $(250 \times 21.4 \mathrm{~mm}$ id, $5 \mu \mathrm{m}$ with cyclohexane- EtOAc $(10: 90)$ in isocratic 187 eluent conditions. This chromatographic purification network led to the isolation of new 188 compounds tamanolides E1 and E2 as a mixture $(2 \mathrm{mg})$ besides standard known compounds namely, calophyllolide, inophyllums (C, D, E, P), calanolides (Gut 70 and A, 12-oxo-calanolide) and tamanolides $(\mathrm{D}, \mathrm{P})$.

191

\section{Analysis of new compounds}

New compounds were identified by NMR and were further analyzed with a Bruker Avance DRX500 spectrometer $\left({ }^{1} \mathrm{H}-500.13 \mathrm{MHz}\right)$ equipped with a $5 \mathrm{~mm}$ triple resonance inverse Cryoprobe TXI $\left({ }^{1} \mathrm{H} /{ }^{13} \mathrm{C} /{ }^{15} \mathrm{~N}\right)$ in $\mathrm{CDCl}_{3}-99.8 \%,\left(\delta_{1 \mathrm{H}}=7.26 \mathrm{pm}, \delta_{13 \mathrm{C}}=77.16 \mathrm{ppm}\right)$. The HR-ESIMS data were collected using a QStar Elite mass spectrometer (Applied Biosystems SCIEX, Concord, ON, Canada) equipped with an ESI source operated in positive ion mode. Optical rotations were measured with a Perkin-Elmer 241 polarimeter equipped with a sodium (589 $\mathrm{nm})$ lamp and a $1 \mathrm{dm}$ cell. The FTIR spectra were established with a Thermo-Nicolet IR 200 spectrometer on a $\mathrm{KBr}$ cell and $4 \mathrm{~cm}^{-1}$ resolution.

201

202

\section{DNA extraction and Amplification}

203

Plant DNA was extracted from young leaf tissue using the Plant Nucleospin ${ }^{\odot}$ II kit (Macherey204 Nagel) according to the manufacturer's instruction. The leaf samples were first lyophilized in 
205 liquid nitrogen and crushed before being subjected to the manufacturer's protocols. Two plant 206 universal chloroplast regions were targeted for amplification namely; the Acetyl-CoA

207 carboxylase $(\mathrm{accD})$ gene and the psaA-ycf3 intergenic spacer region. The amplifications were 208 performed in a Thermo Scientific Arktik Thermo Cycler. The PCR was performed using a 209 Qiagen Taq polymerase kit and primers were diluted to a concentration of $0.6 \mu \mathrm{M}$. All sample 210 amplifications were eluted in distilled milliQ water at $50 \mu \mathrm{L}$ volumes and tested for yield with 1

$211 \%$ agarose gel electrophoresis. The PCR program consisted of $92{ }^{\circ} \mathrm{C}$ of incubation during 2 mins

212 for 1 cycle and 8 cycles of PCR (denaturation at $92{ }^{\circ} \mathrm{C}$ for $30 \mathrm{sec}$ followed by specific annealing 213 temperatures for accD $\left(44^{\circ} \mathrm{C}\right)$ and psaA-ycf3 $\left(43^{\circ} \mathrm{C}\right)$ all at $30 \mathrm{sec}$, and $72{ }^{\circ} \mathrm{C}$ for $\left.1 \mathrm{~min}\right)$,

214 followed by 40 cycles of $\left(92{ }^{\circ} \mathrm{C}\right.$ for $30 \mathrm{sec}$, extension at primer specific temperature's accD (46

$215{ }^{\circ} \mathrm{C}$ ) and psaA-ycf3 at $30 \mathrm{sec}, 72{ }^{\circ} \mathrm{C}$ for $1 \mathrm{~min}$ ). A final $5 \mathrm{~min}$ extension was then carried out at 72

$216{ }^{\circ} \mathrm{C}$ and for only 1 cycle.

217

\section{Sequencing Alignment and Data Analysis}

219 The samples were sequenced by GATC Biotech sequencing services, Germany. Data received in 220 AB1 format were viewed under the Applied Biosystem's sequencing scanner and corrected for 221 contiguous read lengths and miscalled sequence data were removed especially in the beginning 222 and at the ends of the raw data files. Files were then aligned using MEGA6 (Tamura et al., 2013)

223 before they were matched to nucleotide sequences using the BLASTn tool available at

224 https://blast.ncbi.nlm.nih.gov/Blast.cgi. Only matches with 96-100 \% similarity were included in

225 the construction of a multiple sequence alignment. Sequences were aligned using ClustalW

226 (Thompson et al., 1994) and trees were generated using the MEGA6 phylogeny tools. New

227 haplotypes were deposited into the NCBI Genbank database using the Bankit tool. Accession

228 numbers are given in Table S3.

229

230

\section{Phylogenetic construction}

231 All newly determined sequences were checked using the sequencer software for peak intensity

232 and also contiguous length. All sequences with contiguous lengths greater than $200 \mathrm{bp}$ were

233 considered for tree construction using MEGA6. Maximum likelihood (ML) trees were

234 constructed for all accD sequences which satisfied our contiguous length criterion. Initial tree(s)

235 for a heuristic search were first obtained by applying Neighbor-Joining (Saitou and Nei, 1987) 
236 and BioNJ algorithms to a matrix of pairwise distances estimated using the Maximum Composite

237 Likelihood (MCL) approach implemented in MEGA, and tree searches were conducted assuming

238 a Tamura-Nei model and a discrete gamma distribution to model evolutionary rate differences

239 among sites $(5$ categories $(+\mathrm{G}$, alpha parameter $=0.1523))$. The analysis involved 18 nucleotide

240 sequences and all positions containing gaps and missing data were eliminated before tree

241 building. There was a total of 234 positions in the final dataset. The optimal tree obtained has

242 been drawn to scale, with branch lengths indicating the number of substitutions per site. A

243 maximum likelihood tree was also constructed for the psaA-ycf3 Fiji sequence data only, as the

244 Tahiti and New Caledonia DNA for this chloroplast region could not be amplified, possibly due

245 to DNA deterioration. A Tamura-Nei model (Tamura and Nei, 1993) was assumed. The optimal

246 tree has been shown, drawn to scale, with branch lengths determined by the number of

247 substitutions per site. Non parametric bootstrap values are shown for internal branches. The

248 analysis of this second data set involved 11 nucleotide sequences. Positions containing gaps and

249 missing data were eliminated. There was a total of 55 positions in this dataset.

250

251 Statistical Analysis

252 Multivariate statistical analysis was applied to all the chemical data in order to reveal the extent

253 to which the 12 major compounds making up the chemical compositions of the 47 C. inophyllum

254 oil resin samples were geographically distributed. Data were normalized by log transformation

255 prior to Principle Component Analysis (PCA). PCA was performed with the package Ade4 using

$256 \mathrm{R}$ version 3.1 software (R Development Core Team, 2018) and a PCA biplot was drawn using

257 Microsoft Excel software. The diversity of chemical compounds that contributed to the highest

258 discrimination at a geospatial level were visualized and a scatter plot was generated from

259 Microsoft Excel.

260

261

RESULTS

262

263 Chemical composition

264 The fractionation, purification and identification of resin extracts (by spectroscopic methods)

265 yielded 11 compounds from commercial tamanu oil (Fig. 2 A-I), which were identified as

266 constituents previously reported (Laure et al., 2008; Leu et al., 2009). In addition to

Peer) reviewing PDF | (2018:10:31814:2:1:NEW 28 Mar 2019) 
267 calophyllolide, inophyllums (C, D, E, P), calanolides (Gut 70 and A, 12-oxo-calanolide) and

268 tamanolides (D, P), these analyses also led to the isolation of two new compounds X1 and X2 as

269 an epimeric mixture. The presence of these 2 compounds X1 and X2 from the same peak in two

270 fractions was clearly shown in ${ }^{1} \mathrm{H}$ theoretical (Fig. 3A) and experimental spectra (Fig. 3B). As

271 the chemical shifts shown in Table 3 of these compounds were quite similar, evidence of their

272 epimeric existence was indicated by ${ }^{1} \mathrm{H}$ NMR revealing more signals than expected from one

273 compound. These most likely correspond to two sets of signals for two very close compounds

274 that we propose here to be X1: tamanolide E1 and X2: tamanolide E2 (Fig. 2J). The chemical

275 characteristics of tamanolide E1 and E2 are: amorphous yellowish powder; $[\alpha]_{25}^{D}=-19.6$ (c

276 0.003, $\left.\mathrm{CHCl}_{3}\right)$. FTIR $\left(\mathrm{CCl}_{4}\right):$ 3075, 2979, 2926, 2908, 2877, 2832, 1740, 1695, 1643, 1606,

$2771575,1461,1382,1209,1152,1121 \mathrm{~cm}^{-1} .{ }^{1} \mathrm{H} \mathrm{NMR}\left(\mathrm{CDCl}_{3}, 500 \mathrm{MHz}\right)$ and ${ }^{13} \mathrm{C}\left(\mathrm{CDCl}_{3}, 125\right.$

$278 \mathrm{MHz}$ ) (see Table 3); HR-ESI-MS m/z $383.1850[\mathrm{M}+\mathrm{H}]^{+}$(calcd. for $\mathrm{C}_{23} \mathrm{H}_{27} \mathrm{O}_{5}, 383.1853$.).

279

280

281

\section{Chemical Diversity of C. inophyllum within the 3 regions}

HPLC analysis of $C$. inophyllum was performed to investigate the phytochemical components of

282 tamanu oil in different samples and their geographical distribution. Eleven isolated compounds

(Fig.4: peaks 1-11), along with two new compounds (Fig.4: peak 12), were used as external standards to qualitatively analyze four sample of $C$. inophyllum from three different locations, Fiji West (FW1), New Caledonia Noumea (N1 and N3) and Rotuma Fiji (R4). The phytochemical components of each sample were identified by comparing the retention time of the external standards (Fig. 4).

The alignment of all samples through $\mathrm{R}$ and Scilab provided a matrix containing the integrated peak area of the identified features. Data were normalized by log transformation prior to PCA analysis. The samples can be discriminated into three main regions (Fig. 5) with the French Polynesian population on the left of the graph, the New Caledonia population on the bottom right and the Fiji population on the upper right. Within French Polynesia and Fiji, no discrimination between the sites or archipelagos was observed with these first two components. The different proportions of the compounds leading to biogeographic discrimination of the three regions is shown in the variables factor map (Fig. 6). The first component, representing $15.8 \%$ of the total variance, discriminated notably tamanolide E1/E2 and Gut 70 calanolide from inophyllum $\mathrm{C}$ and tamanolides $\mathrm{D}$ and $\mathrm{P}$. The proportion of tamanolide E1/E2, Gut 70 calanolide, 
298 tamanolide and inophyllum E were the main and significant compounds prominent in the

299 composition of the oil resin from French Polynesia, while tamanolide P, D and inophyllum C

300 were more prominently represented in the Fiji samples. The second component (7.6\% of the

301 total variance) discriminated mainly unknown compounds and calophyllolide, compound P73

302 positively and calophyllolide, P45, P50 and P69 negatively. Characteristic of the oil resin from

303 New Caledonia were constituents such as calophyllolide and compound P69, which although

304 unknown and unidentified, appeared to be unique in its occurrence as suggested by the PCA

305 analysis. The chemical diversity of the Tahiti samples namely from the Tuamotu's and Australes

306 as seen in Fig. 5, were also unique with the presence of the compound P73.

307

308 Genetic discrimination

309 MEGA 6 identified the Tamura-Nei model as the best fitting model in ML analyses.

310 Phylogenetic relationships assuming this model of substitution for C. inophyllum are shown in

311 Fig. 7A and Fig. 7B for the accD gene and for the psaA-ycf3 spacer region, respectively.

312 Interestingly, only Raiatea from French Polynesia showed a unique genotype, where it produced

313 two new haplotypes (T22 and T23) in the accD tree caused by substitutions at positions 134bp

314 and 146bp.

315

316

\section{DISCUSSION}

317

318

\section{New chemical isolates and chemical variability}

Compounds $\mathrm{X} 1$ and $\mathrm{X} 2$ had a molecular formula of $\mathrm{C}_{23} \mathrm{H}_{27} \mathrm{O}_{5}$ as determined by high-resolution mass spectrum (HR-ESI-MS) (m/z $383.1850[\mathrm{M}+\mathrm{H}]+$, calcd 383.1853) and NMR data implying 11 degrees of unsaturation (Table 3, Fig. S1-S10). The ${ }^{13} \mathrm{C}$ NMR spectrum gave a total of 23 separated resonances and the 135-DEPTQ sequence showed the presence of six methyl, one methylene, six methine and ten quaternary carbons including a ketone carbonyl at $\delta 191.7 \mathrm{ppm}$ for compounds X1 and X2. The ${ }^{1} \mathrm{H}$ resonances of both compounds (Fig. S1 and S9) were typical of a pyranocoumarin as characterized by the downfield shifted proton at $\delta 6.16(1 \mathrm{H}, \mathrm{s}, \mathrm{H}-3)$ for an $\alpha, \beta$-unsaturated lactone (ring B), and a set of doublet signals $[\delta 6.66 \mathrm{ppm}(1 \mathrm{H}, \mathrm{d}, \mathrm{J}=10.0 \mathrm{~Hz}$, $\mathrm{H}-8), 5.60 \mathrm{ppm}(1 \mathrm{H}, \mathrm{d}, \mathrm{J}=10.0 \mathrm{~Hz}, \mathrm{H}-7)]$, and two methyl singlets at $\delta 1.54 \mathrm{ppm}(3 \mathrm{H}, \mathrm{s}, \mathrm{H}-19)$ 
328 and $\delta 1.54(3 \mathrm{H}, \mathrm{s}, \mathrm{H}-20)$ for the first one (X1) and at $\delta 1.53 \mathrm{ppm}(3 \mathrm{H}, \mathrm{s}, \mathrm{H}-19)$ and $\delta 1.53 \mathrm{ppm}$

329 (3H, s, H-20) for the second one (X2), for a pyrane ring (ring C).

330

331 Furthermore, the cycle ring D showed a characteristic cis-configuration with a coupling constant 332 of $3.4 \mathrm{~Hz}$ between $\mathrm{H}-10 \delta 4.69$ ppm $(1 \mathrm{H}, \mathrm{qd}, \mathrm{J}=6.5,3.4 \mathrm{~Hz})$ and $\mathrm{H}-11 \delta 2.68 \mathrm{ppm}(1 \mathrm{H}, \mathrm{qd}, \mathrm{J}=$ $3337.2,3.4 \mathrm{~Hz})$ for $\mathrm{X} 1$ and between $\mathrm{H}-10 \delta 4.70 \mathrm{ppm}(1 \mathrm{H}, \mathrm{qd}, \mathrm{J}=6.5,3.4 \mathrm{~Hz})$ and $\mathrm{H}-11 \delta 2.69 \mathrm{ppm}$ $334(1 \mathrm{H}, \mathrm{qd}, \mathrm{J}=7.2,3.4 \mathrm{~Hz})$ for X2 and by NOE crosspeaks correlation between the two methyl 335 groups $\mathrm{H}-21 \delta 1, .42 \mathrm{ppm}(3 \mathrm{H}, \mathrm{d}, \mathrm{J}=6.6 \mathrm{~Hz}), \mathrm{H}-22 \delta 1, .15 \mathrm{ppm}(3 \mathrm{H}, \mathrm{d}, \mathrm{J}=7.2 \mathrm{~Hz})$ for X1, and $336 \mathrm{H}-21 \delta 1, .41 \mathrm{ppm}(3 \mathrm{H}, \mathrm{d}, \mathrm{J}=6.6 \mathrm{~Hz}), \mathrm{H}-22 \delta 1, .15 \mathrm{ppm}(3 \mathrm{H}, \mathrm{d}, \mathrm{J}=7.2 \mathrm{~Hz})$ for $\mathrm{X} 2$, like 337 inophyllum E.

338 With the aid of the COSY experiment, an isobutyl unit was identified by further analysis of the 339 remaining ${ }^{1} \mathrm{H}$ resonances $[\delta 3.79 \mathrm{ppm}(1 \mathrm{H}$, brsxt, $\mathrm{J}=7.0 \mathrm{~Hz}, \mathrm{H}-13), 1.75 \mathrm{ppm}(1 \mathrm{H}, \mathrm{m}, \mathrm{H}-14 \mathrm{a})$, $3401.45 \mathrm{ppm}(1 \mathrm{H}, \mathrm{m}, \mathrm{H}-14 \mathrm{~b}), 0.95 \mathrm{ppm}(3 \mathrm{H}, \mathrm{t}, \mathrm{J}=7.4 \mathrm{~Hz}, \mathrm{H}-15)$ and $1.22 \mathrm{ppm}(3 \mathrm{H}, \mathrm{d}, \mathrm{J}=6.7 \mathrm{~Hz}$, $341 \mathrm{H}-16)]$ for X1 and $\delta 3.79 \mathrm{ppm}(1 \mathrm{H}$, brsxt, $\mathrm{J}=7.0 \mathrm{~Hz}, \mathrm{H}-13), 1.75 \mathrm{ppm}(1 \mathrm{H}, \mathrm{m}, \mathrm{H}-14 \mathrm{a}), 1.45 \mathrm{ppm}$ 342 (1H, m, H-14b), $0.96(3 \mathrm{H}, \mathrm{t}, \mathrm{J}=7.4 \mathrm{~Hz}, \mathrm{H}-15)$ and $1.22 \mathrm{ppm}(3 \mathrm{H}, \mathrm{d}, \mathrm{J}=6.7 \mathrm{~Hz}, \mathrm{H}-16)]$ for X2. 343 This isobutyl moiety was assigned to be at the C-4 position, based on the HMBC crosspeaks between H-3 ( $\delta 6.16 \mathrm{ppm})$ and C-13 ( $\delta 37.5$ ppm), between H-16 ( $\delta 1.22 \mathrm{ppm})$ and C-4 ( $\delta 104.7$ ppm), between H-14 ( $\delta 1.45,1.75$ ppm) and C-4 ( $\delta 104.7$ ppm), between H-13 ( $\delta 3.79$ ppm) and the carbons C-3 ( $\delta 109.3 \mathrm{ppm})$ and C-4a $(\delta 104.7 \mathrm{ppm})$. The rest of the HMBC correlations used to obtain a complete assignment of the ${ }^{1} \mathrm{H}$ and ${ }^{13} \mathrm{C}$ NMR chemical shift, have been summarized and presented in Table 3. The ${ }^{1} \mathrm{H}$ and ${ }^{13} \mathrm{C}$ NMR of both compounds were almost identical to those of inophyllum $\mathrm{E}$ with the exception of an isobutyl group at C-4 and tamanolide $\mathrm{D}$ with the exception of the ring D.

351 Complete assignments of X1 and X2 were made based on 1D and 2D NMR experiments, of 352 which compound X1 was suggested as tamanolide E1 while compound X2 was the H-13 epimer of X1 and suggested as tamanolide E2. Proton NMR spectrum (Fig. 3) of different HPLC

354 fractions revealed X1 and X2 as a mixture from two compounds whose signals were close to 355 each other with a varied ratio (from $70 / 30$ to 40/60). The chemical shifts of both compounds are listed in Table 3. Different fractions of a collected HLPC peak show a variation of proportion related to these two epimer compounds X1 and X2 and corresponding to two close set of signals 
358 in the ${ }^{1} \mathrm{H}$ NMR spectrum (Fig. 3). Assignment of the resonances was based on the $1 \mathrm{D}$ and 2D

359 NMR experiments (1H, 13C-DEPTQ135, COSY, HSQCed, HMBC and NOESY).

360 Finally, the structures of 11 known compounds are shown (Fig. 2) including the two new

361 compounds assigned as tamanolide E1 and E2 after elucidation from exhaustive NMR analysis

362 (1H, 13C-DEPTQ135, COSY, HSQCed, HMBC, NOESY), including the comparison of

363 experimental and theoretical results (Fig. 3A and B) and by comparison with NMR data of the

364 phenylcoumarin back bone from inophyllum E and tamanolide D.

365 Consistent with earlier findings (Prabakaran and Britto, 2012; Laure et al., 2008), calophyllolide

366 remains as the dominant major compound in tamanu resin for all isolated chemotypes.

367 Calanolide A which is the most potent of all C. inophyllum compounds with anti-HIV-1 activity

368 (Wang et al., 2006) was found as a minor component in C. inophyllum oil. The

369 pyranocoumarines inophyllum B and P (also active against HIV-1) were also isolated. The

370 former is not only the most active but is also the only natural product undergoing clinical trials

371 against HIV-1 (Liang, 2006). As seen in Fig. 4, the $280 \mathrm{~nm}$ UV spectrum revealed the maximum

372 number of peaks and therefore standards and samples were targeted for visualization at this

373 wavelength.

374 All the standards isolated here as seen in Fig. 4 have been isolated in previous studies from

375 French Polynesian C. inophyllum oil (Leu et al., 2009a; Leu et al., 2009b; Laure, 2005). A

376 unique characteristic of $C$. inophyllum oil is the presence of a resin which has been shown to

377 contain neoflavonoid biologically active constituents (Ansel et al., 2016). Previous studies by

378 McKee et al., 1998 and Li et al., 2007 have indicated the use of HPLC analyses to investigate

379 differences in chemical profiles from different populations. In our case, we have looked at

380 samples from three localities. The population from New Caledonia was characterised by peaks

381 not found in earlier studied populations and these novel peaks suggest new and specific

382 chemomarkers. Unique to this study as shown in the biplot on Figure 6 is that we were able to

383 show the chemodiversity of tamanu resin oil across the three study sites based on chemical

384 compounds that contribute to the highest discrimination at a geographical level from the PCA

385 analysis. This point is important and rather unique in the study as this reveals the chemical

386 specificity of compounds and their proportions in tamanu resin by geographical locations across

387 the South Pacific.

388

Peer] reviewing PDF | (2018:10:31814:2:1:NEW 28 Mar 2019) 
389

390

391

392

393

394

395

396

397

398

399

400

401

402

403

404

405

406

407

408

409

410

411

412

413

414

415

416

417

418

419

\section{DNA variability}

This is the first reported work on C. inophyllum using the universal chloroplast barcoding regions the gene accD and the intergenic region psaA-ycf3. Low levels of genetic variation were found with these markers, and this variation was not functionally linked to differences in chemical composition. The absence of genetic variation among Fiji psaA-ycf3 regions suggests low genetic variation in C. inophyllum. However, analyses of additional chloroplast gene regions or nuclear ISSR markers may yet reveal more discrimination within the Fiji archipelago and between populations from different archipelagos.

\section{CONCLUSIONS}

Our results are informative in revealing that chemical differences in tamanu resin can be a tool for the discrimination of samples and geographic regions. In our case, chromatographic data proved to be more informative and highly discriminative than DNA barcoding data, possibly owing to low genetic variation in the used chloroplast regions. Additional chloroplast barcoding regions or utilization of nuclear microsatellites may give a better perspective on patterns of genetic diversity. Of interest were haplotypes (T22 and T23) which were distinct from the more commonly found C. inophyllum genotype. Polyphasic taxonomy that considers both chemical diversity and genetic diversity presents the best approach to delineate biological variation across geographical boundaries. However, higher levels of genetic resolution are required to characterize variation in the disjunct distribution of C. inophyllum across the South Pacific and to bring insight into the diversification processes that have occurred following geographic isolation. This diversification includes the evolution of novel pyranocoumarins compounds characterized by this study: tamanolide E1 and E2 (C-13 epimers as a mixture).

\section{ACKNOWLEDGEMENTS}

This paper is dedicated to the memory of our wonderful colleague, supervisor and friend Prof William Aalbersberg who has passed away. We thank and greatly appreciate him for his wisdom and inspiring research leadership. We are grateful to the people of French Polynesia, Fiji and New Caledonia for giving us access to sampling areas to collect our nuts and leaf samples. We 
420 thank Cloe Check, Juliette Prevost, Nicolas Martin, and Ranitea Ly for performing HPLC

421 analysis on all the samples. We also thank Mr. John Bennett for supplying oil extracts and 422 assisting in the processing of samples in Fiji as well as Mr. Olivier Touboul (LCPS) for tamanu 423 sample collection in French Polynesia. Special thanks to Mr. Marika Tuiwawa and Mr. Alivereti

424 Naikatini for their assistance in the sample collection and deposition of samples in Fiji. 425

426

\section{REFERENCES}

427 Angiosperm Phylogeny Group, 2009. An update of the Angiosperm Phylogeny Group 428 classification for the orders and families of flowering plants: APG III. Botanical Journal of the 429 Linnean Society 161: 105-121 DOI : 10.1111/j.1095-8339.2009.00996

430 Ansel J , Lupo E, Mijouin L, Guillot S , Butaud J , Ho R , Lecellier G, Raharivelomanana P, 431 Pichon C. 2016. Biological activity of Polynesian Calophyllum inophyllum oil extract on human 432 skin cells. Planta Medica 82 : 961-966. DOI : 10.1055/s-0042-108205 Assouvie N. 2013. Le Tamanu (Calophyllum inophyllum L.) en Polynésie Française et autre espèces du genre Calophyllum: De l'usage en médecine traditionnelle à l'émergence d'un médicament anti-VIH. Thèse de doctorat en pharmacie, Université de Bordeaux Ségalen, p 122, $\mathrm{n}^{\circ}$ 2013BOR2P019.

437 Bhalla TN, Saxena RC, Nigam SK, Misra G, Bhargava KP. Calophyllolide-A new non-steroidal anti-inflammatory agent. Indian Journal of Medicinal Research. 1980, 72, 762765.

440 Boudreau E, Takahashi Y, Lemieux M., and Rochaix, J.-D. (1997). The chloroplast ycf3 and 441 ycf4 open reading frames of Chlamydomonas reinhardtii are required for the accumulation of the photosystem I complex. EMBO J. 16, 6095-6104. DOI: 10.1093/emboj/16.20.6095 Cambie RC, and Ash J. 1994. Dicotyledons in Fijian Medicinal Plants. CSIRO Australia, 119 444 120.

Dweck AC and Meadows T. 2002. Tamanu (Calophyllum inophyllum) - the African, Asian, Polynesian and Pacific Panacea. Internationl Journal of Cosmetic Sciences. 24(6):341-8. DOI: 10.1046/j.1467-2494.2002.00160.x.

Friday JB, and Okano D. 2006. Calophylum inophyllum (Kamani). Species profiles for Pacific Island Agroforestry. Ver 2.1. Permanent Agriculture Resources (PAR), Hōlualoa, Hawai'i. 
451 Hu Y, Zhang Q, Xin H, Qin L-P, Lu B-R, Rehman K, Zheng H (2007). Association between

452 chemical and genetic variation of Vitex roduntifolia population from different locations in China:

453 its implication for quality control of medicinal plants. Biomedical Chromatography 21:967-975.

454 DOI: 10.1002/bmc.841

455 Ishikawa, T. 2000. Anti HIV-1 Active Calophyllum Coumarins: Distribution, Chemistry and 456 Activity. Heterocycles 53 (2) : 453-474. DOI: 10.3987/REV-99-526

457 Itoigawa M, Ito C, Hugh T , Tan W , Kuchide M, Tokuda H , Nishino H , Furukawa H. 2001.

458 Cancer chemo preventive agents, 4-phenylcoumarins from Calophyllum inophyllum. Cancer

459 Letters 169 : 15-19. DOI : 10.1016/S0304-3835(01)00521-3

460 Jin L, Tabe Y, Kimura S, Zhou Y, Kuroda J , Asou H , Inaba T, Konopleva M, Andreeff M,

461 Miida T. 2011. Antiproliferative and proapoptotic activity of GUT-70 mediated through potent

462 inhibition of Hsp90 in mantle cell lymphoma. British Journal of Cancer 104 : 91 - 100. DOI:

463 10.1038/sj.bjc.6606007

464 Kostova I, and Mojzis J. 2007. Biologically active coumarins as Inhibitors of HIV-1. Future HIV

465 Therapy 1(3): 315-329. DOI: 10.2217/17469600.1.3.315

466 Lahaye R, Van der Bank M, Bogarin D, Warner J, Pupulin F, Gigot G, Maurin O, Duthoit S,

467 Barraclough T, and Savolainen V. 2007. DNA barcoding the floras of biodiversity hotspots.

468 PNAS Vol 5 (8): 2923-2928. DOI: 10.1073 /pnas.0709936105

469 Lam V, Merckx V, and Graham S. 2016. A few-gene plastid phylogenetic framework for

470 mycoheterotrophic monocots. American Journal of Botany 103(4): 1-17. DOI:

$47110.3732 /$ ajb.1500412

472 Laure F. 2005. Etude de la composition chimique et de la biodiversité du Calophyllum

473 inophyllum de Polynésie Française. Thèse de doctorat de chime, Université de la Polynésie

474 Française, p 357, $\mathrm{n}^{\circ}$ 2005POLF0001.

475 Laure F, Raharivelomanana P, Butaud J-F, Bianchini J-P, Gaydou EM. 2008. Screening for Anti476 HIV-1 inophyllums by HPLC-DAD of Calophyllum inophyllum leaf extracts from French

477 Polynesia Islands. Analytica Chimica Acta 624: 147-153. DOI: 10.1016/j.aca.2008.06.046

478 Léguillier T, Lecsö-Bornet M, Lémus C, Rousseau-Ralliard D, Lebouvier N, Hnawia E, Nour M,

479 Aalbersberg W, Ghazi K, Raharivelomanana P, Rat P. 2015. The Wound Healing and

480 Antibacterial Activity of Five Ethnomedical Calophyllum inophyllum Oils: An Alternative 
481 Therapeutic Strategy to Treat Infected Wounds. PLoS ONE 10 (9):1-20. DOI:

482 10.1371/journal.pone.0138602

483 Leu T, Raharivelomanana P, Soulet S, Bianchini J-P, Herbette G and Faure R. 2009. New

484 tricyclic and tetracyclic pyranocoumarins with an unprecedented C-4 substituent. Structure

485 elucidation of Tamanolide, Tamanolide D and Tamanolide P from Calophyllum inophyllum of

486 French Polynesia. Magnetic Resonance in Chemistry 46: 989-993. DOI: 10.1002/mrc.2482

487 Leu T. 2009. Contribution à la connaissance de la flore polynésienne: évaluation de l'intérêt

488 pharmacologique de quelques plantes médicinales et étude phytochimique du Tamanu

489 (Calophyllum inophyllum L. - Clusiaceae) [dissertation]. Papeete, Tahiti: Université de la

490 Polynésie Française.

491 Li HL, Zhang WD, Zhang C, Han T, Liu R-H, Hu J, Chen HS. 2007. Comparative analysis of

492 chemical profile of wild and cultivated populations of Corydalis saxicola by high performance

493 liquid chromatography. Phytochemical Analysis 18:393-400. DOI: 10.1002/pca.994

494 Lynch RC, Vergara D, Tittes S, White K, Schwartz CJ, Gibbs MJ, Ruthenburg TC, deCesare K, 495 Land, DP \& Kane, NC (2016). Genomic and Chemical Diversity in Cannabis. Critical Reviews 496 in Plant Sciences 35: (6), 349-363. DOI: 10.1080/07352689.2016.1265363

497 Nei M, and Kumar S. 2000. Molecular Evolution and Phylogenetics. Oxford University Press, 498 New York.

499 McKee TC, Covington CD, Fuller RW, Bokesch HR, Young S, Cardellina JH II, Kadushin MR, 500 Soejarto DD, Stevens P, Cragg GM, Boyd MR. 1998. Pyranocoumarins from tropical species of 501 genus Calophyllum: a taxonomic study of extracts in National Cancer Institute Collection.

502 Journal of Natural Products 61:1252-1256. DOI: 10.1021/np980140a

503 Patil AD, Freyer AJ, Eggleston DS, Haltiwanger RC, Bean MF, Taylor PB, Caranfa MJ, Breen

504 AL, Bartus HR, Johnson RK, Hertzberg RP, Westley JW. 1993. The Inophyllums, novel 505 inhibitors of HIV-1 reverse transcriptase isolated from Malaysian tree, Calophyllum inophyllum 506 Linn. Journal of Medicinal Chemistry 36: 4132-4138. DOI: 10.1021/jm00078a001

507 Pawar KD, Swati JP, Shubhada RT. 2011. Association between chemical and genetic variation in 508 Calophyllum inophyllum, a medicinally important tree of the Western Ghats of India. Plant

509 Systematic Evolution 292: 257-265. DOI 10.1007/s00606-010-0409-8 
510 Prabakaran K, Britto SJ. 2012. Biology, Agroforestry and Medical Value of Calophyllum

511 inophyllum L. (Clusiacea): A Review. International Journal of Natural Products Research 1 (2):

512 24-33.

513 Quisumbing E. 1951. Medicinal Plants of the Philippines. In Dweck, A.C and Meadows, T.

514 2002. Tamanu (Calophyllum inophyllum) - the African, Asian, Polynesian and Pacific Panacea.

515 International Journal of Cosmetic Science (24): 1-8. DOI: 10.1046/j.1467-2494.2002.00160

516 R Core Team. 2018. R: A language and environment for statistical computing. R Foundation for

517 Statistical Computing, Vienna, Austria. URL https:/www.R-project.org/

518 Ruf S, Kossel H, and Bock, R. (1997). Targeted inactivation of a tobacco intron-containing open

519 reading frame reveals a novel chloroplast-encoded photosystem I-related gene. Journal of Cell

520 Biology 139, 95-102. DOI: 9314531.

521 Rzhetsky A, and Nei, M. 1992. A simple method for estimating and testing minimum evolution

522 trees. Molecular Biology and Evolution 9: 945-967.

523 DOI: 10.1093/oxfordjournals.molbev.a040771

524 Saitou N, and Nei M. 1987. The neighbor-joining method: A new method for reconstructing

525 phylogenetic trees. Molecular Biology and Evolution 4: 406-425. DOI:

\section{10.1093/oxfordjournals.molbev.a040454}

527 Saravanan, R \& Dhachinamoorthi, D \& Senthilkumar, K \& Thamizhvanan, K. (2011).

528 Antimicrobial activity of various extracts from various parts of Calophyllum inophyllum L..

529 Journal of Applied Pharmaceutical Science 1. 102-106.

530 Saxena RC, Nath R, Palit G, Nigam SK, Bhargava KP. 1982. Effect of Calophyllolide, a non-

531 steroidal anti-inflammatory agent, on capillary permeability. Journal of Medicinal Plant

532 Research 44(4): 246-248. DOI: 10.1055/s-2007-971459

533 Scilab Enterprises .2012. Scilab: Free and Open Source software for numerical computation

534 (Windows 8, Version 5.5.1) [Scilab]. Available from: http://www.scilab.org

535 Tamura, K. 1992. Estimation of the number of nucleotide substitutions when there are strong

536 transition-transversion and G + C-content biases. Molecular Biology and Evolution 9: 678-687.

537 DOI: 10.1093/oxfordjournals.molbev.a040752

538 Tamura K, Stecher G, Peterson D, Filipski A, and Kumar S. (2013). MEGA6: Molecular

539 Evolutionary Genetics Analysis version 6.0. Molecular Biology and Evolution 30: 2725-2729. 
540 Tamura K. and Nei M. (1993). Estimation of the number of nucleotide substitutions in the

541 control region of mitochondrial DNA in humans and chimpanzees. Molecular Biology and

542 Evolution 10:512-526. DOI: 0131 4038/93/1003-0

543 Thompson JD, Higgins DG, and Gibson TJ. (1994). CLUSTAL W: improving the sensitivity of

544 progressive multiple sequence alignment through sequence weighting, position-specific gap

545 penalties and weight matrix choice. Nucleic Acids Research. 22 (22): 4673-4680. DOI:

$54610.1093 /$ nar/22.22.4673

547 Vandamme P, Pot B, Gillis M, de Vos P, Kersters K, Swings J. Polyphasic taxonomy, a

548 consensus approach to bacterial systematics. Microbiological Reviews. 1996;60(2):407-38. DOI:

549 PMC239450

550 Wang L, Ma T, and Liu G. 2006. Recent Progress in Calophyllum Coumarins as Potent Anti-

551 HIV Agents In Liang, X.; and Fang, W. 2006. Medicinal Chemistry of Medicinal Natural

552 Products. Wiley-Interscience. pp 325-350. DOI: doi.org/10.1002/0471739340.ch8

553 Wang S, Ho T, Kuo C, Tseng C. 2010. Chromaligner: a web server for chromatogram alignment.

554 Bioinformatics 26 (18): 2338-2339. DOI: 10.1093

555 Yimdjo MC, Azebaze GA, Nkengfack AE, Meyer AM, Bodo B, Fomum ZT. 2004.

556 Antimicrobial and cytotoxic agents from Calophyllum inophyllum. Phytochemistry 65: 2789-

557 2795. DOI: 10.1016/j.phytochem.2004.08.024

558 Xi, Z; Ruhfel, R. B; Schaefera, H; Amorimd, A. M; Sugumarane, M; Wurdack, K. J; Endress, P.

559 K; Matthews, M. L; Stevens, P. F; Mathews, S; and Davis, C. 2012. Phylogenomics and a

560 posteriori data partitioning resolve the Cretaceous angiosperm radiation Malpighiales. PNAS

561 109(43): 17519-17524. DOI: 10.1073/pnas.1205818109

562 


\section{Figure 1}

Map of the Oceania with the three sampled locales

Map was downloaded from the works of Peter Fitzgerald on the Oceania Regions ( https://commons.wikimedia.org/wiki/File:Oceania_regions map.png ) and the three sampled locales are indicated in added red boxes. This Figure is licensed under CC BY-SA 3.0 ( https://creativecommons.org/licenses/by-sa/3.0/deed.en ).

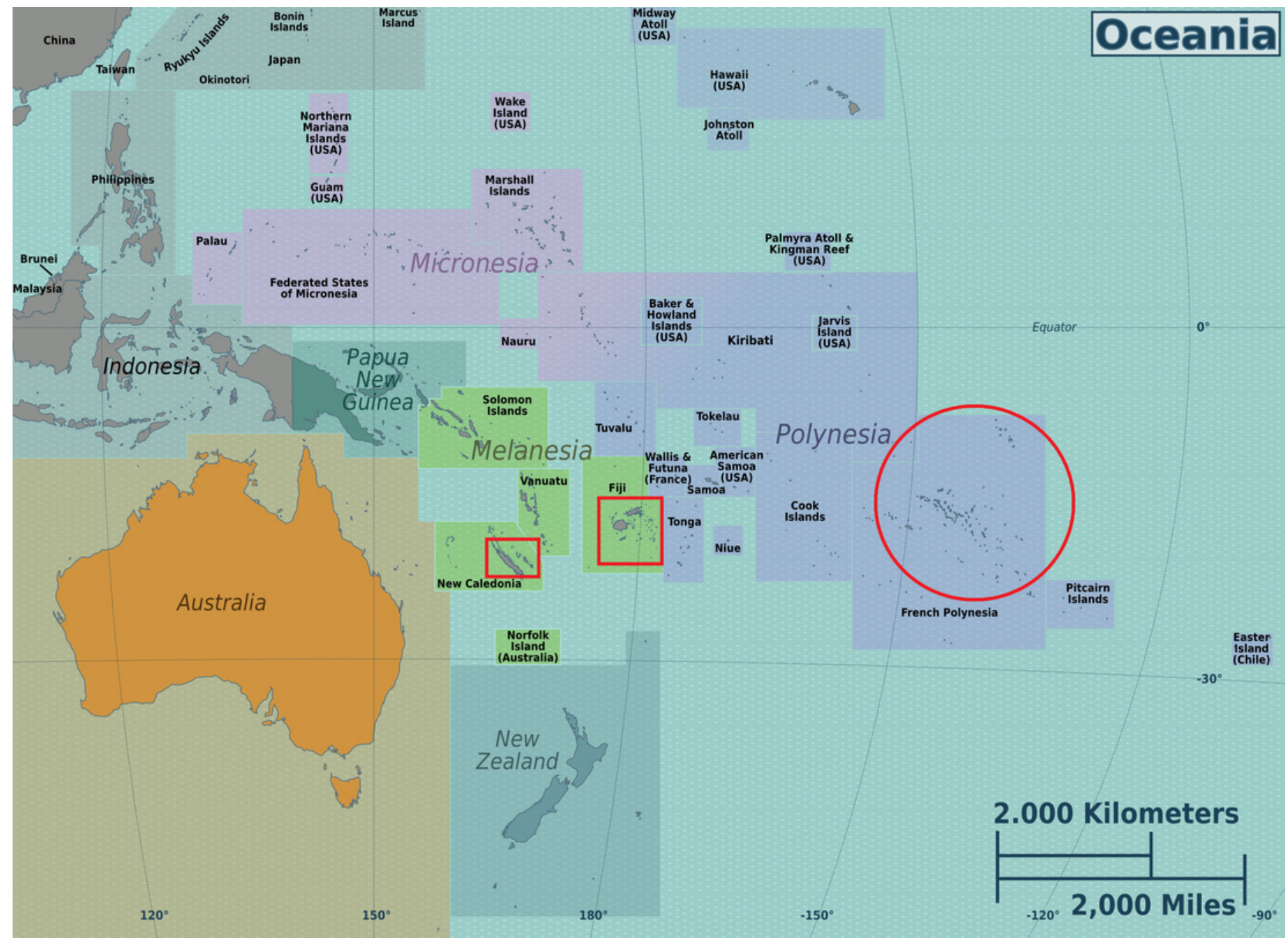


Figure 2

Structures of isolated compounds

(A) Calophyllolide, (B) Calanolide GUT 70, (C) Tamanolide, (D) Inophyllums P, D and C, (E) Tamanolide P, (F) 12-Oxo-calanolide, (G) Calanolide A, (H) Inophyllum E, (I) Tamanolide D and (J) Tamanolide E1,E2

*Note: Auto Gamma Correction was used for the image. This only affects the reviewing manuscript. See original source image if needed for review. 
<smiles>CC=C(C)C(=O)c1c(OC)c2c(c3c(-c4ccccc4)cc(=O)oc13)OC(C)(C)C=C2</smiles>

A

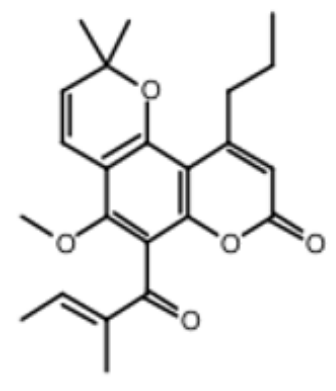

B

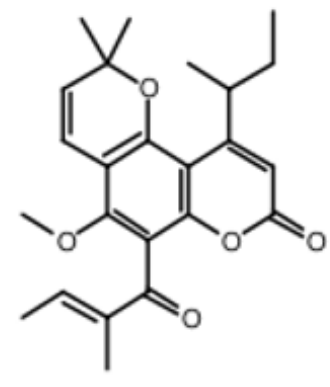

C<smiles>[Y9][C@H]1c2c(c3c(c4c(-c5ccccc5)cc(=O)oc24)OC(C)(C)C=C3)O[C@H](C)C1([R2])[R]</smiles>

D<smiles>CCCc1cc(=O)oc2c3c(c4c(c12)OC(C)(C)C=C4)O[C@H](C)[C@@H](C)C3=O</smiles>

F<smiles>CCC(C)c1cc(=O)oc2c3c(c4c(c12)OC(C)(C)C=C4)O[C@H](C)[C@H](C)[C@H]3O</smiles>

$\mathbf{E}$<smiles>CCCc1cc(=O)oc2c3c(c4c(c12)OC(C)(C)CC4)O[C@H](C)[C@H](C)[C@H]3C</smiles>

G

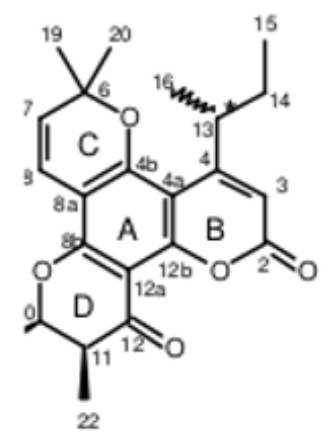

J 
Figure 3

The superimposition of two NMR spectra's of the mixture of tamanolide E1 and E2 at different proportions (40/60 and 70/30)

A) Experimental (black) and theoretical (E1: red and E2: blue) $1 \mathrm{H}$ NMR and B) spectra $\mathrm{CDCl} 3$

$-500 \mathrm{MHz}$ 
A

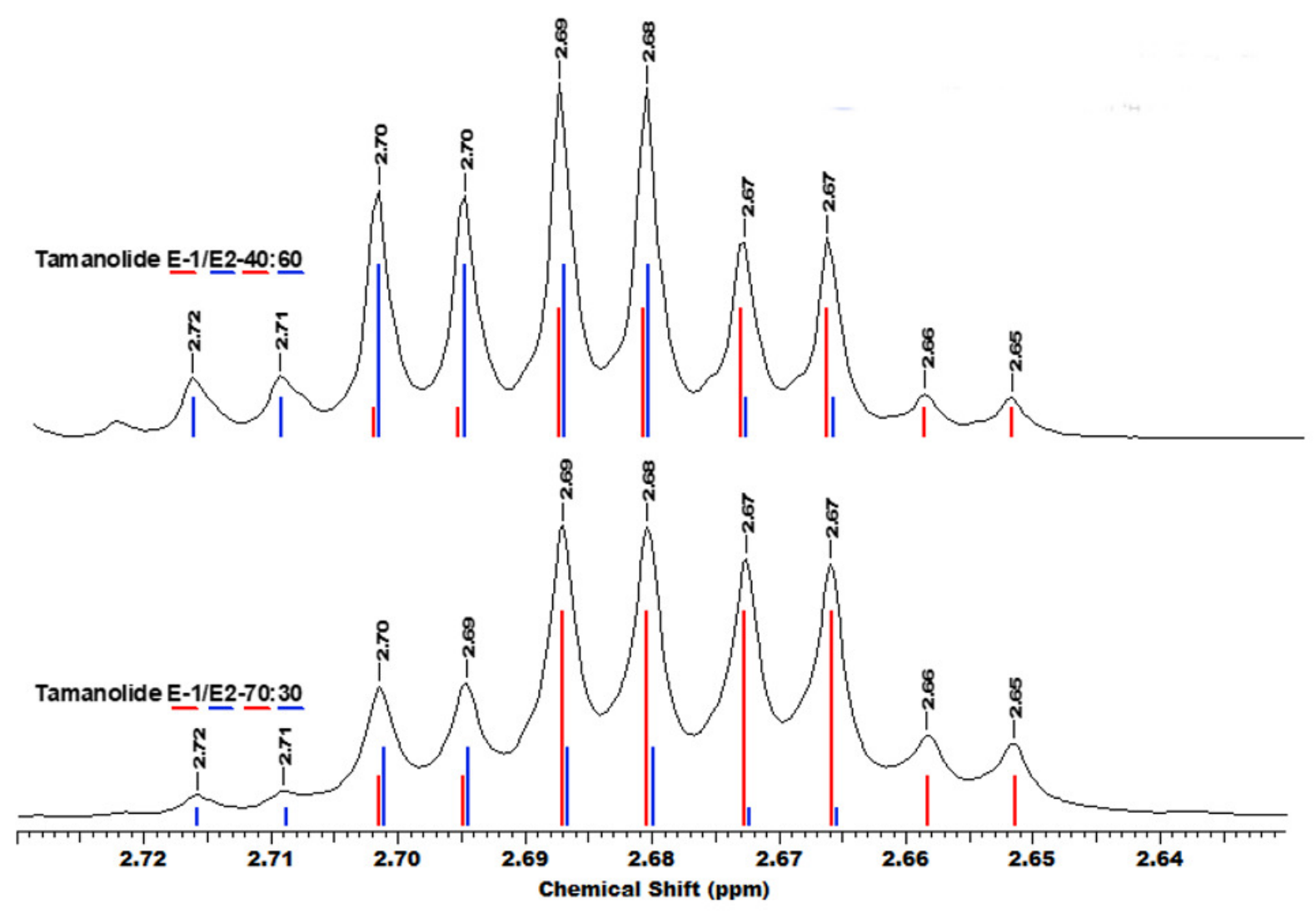

B

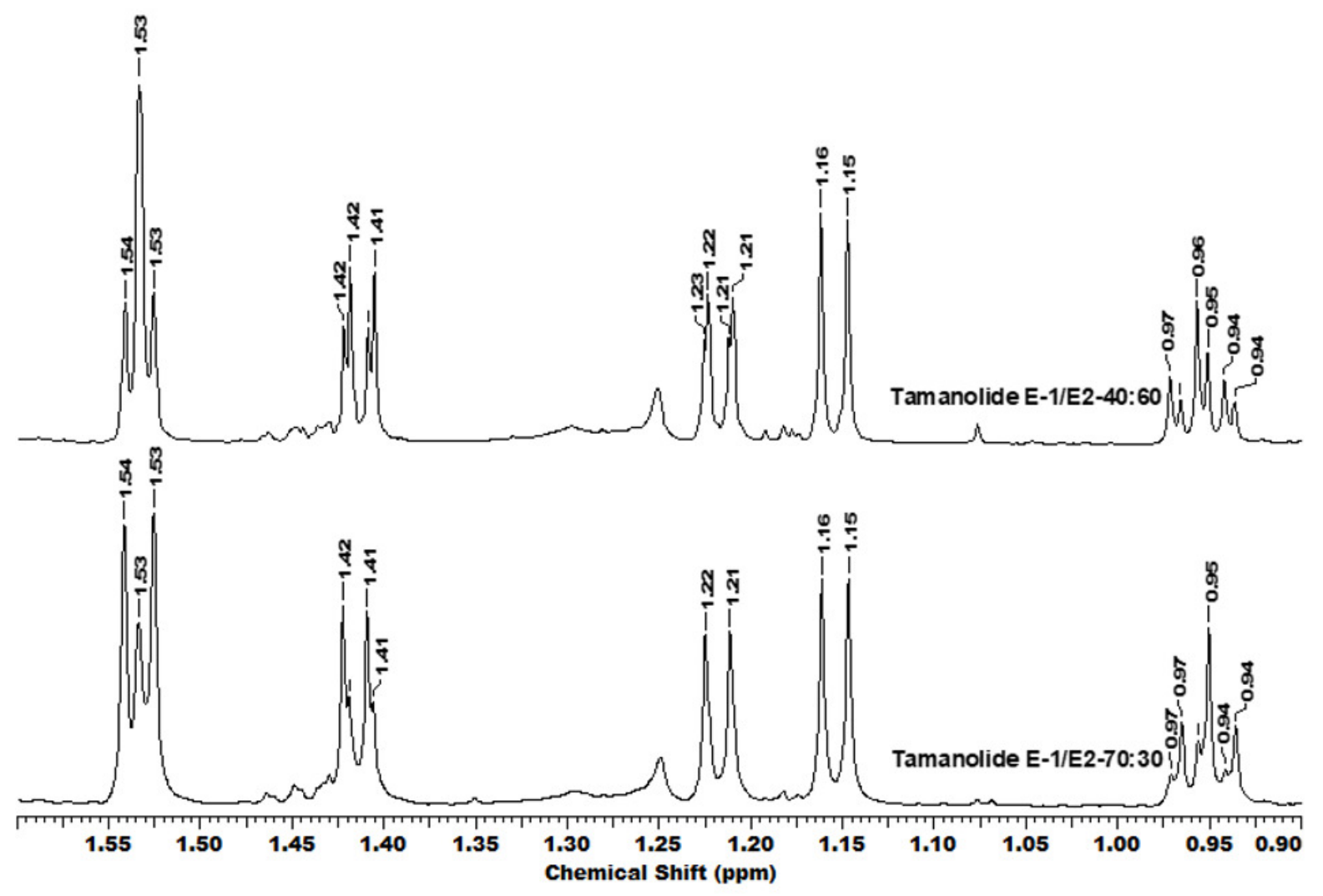




\section{Figure 4}

Four representative HPLC chromatograms superimposed at $\lambda 280 \mathrm{~nm}$ UV range detection.

The standard peaks, (1) calophyllolide, (2) tamanolide, (3) calanolide Gut 70, (4) inophyllum

D, (5) tamanolide $D$, (6) calanolide $A$, (7) inophyllum $P,(8)$ tamanolide $P,(9)$ inophyllum C, (10) 12-oxo-calanolide, (11) inophyllum E, (12) tamanolide E1/E2, have been assigned in the chromatogram for Fiji West FW1 (orange), Rotuma Fiji sample R4 (light blue) and two New Caledonia Noumea samples N3 (dark red) and N1 (dark blue).

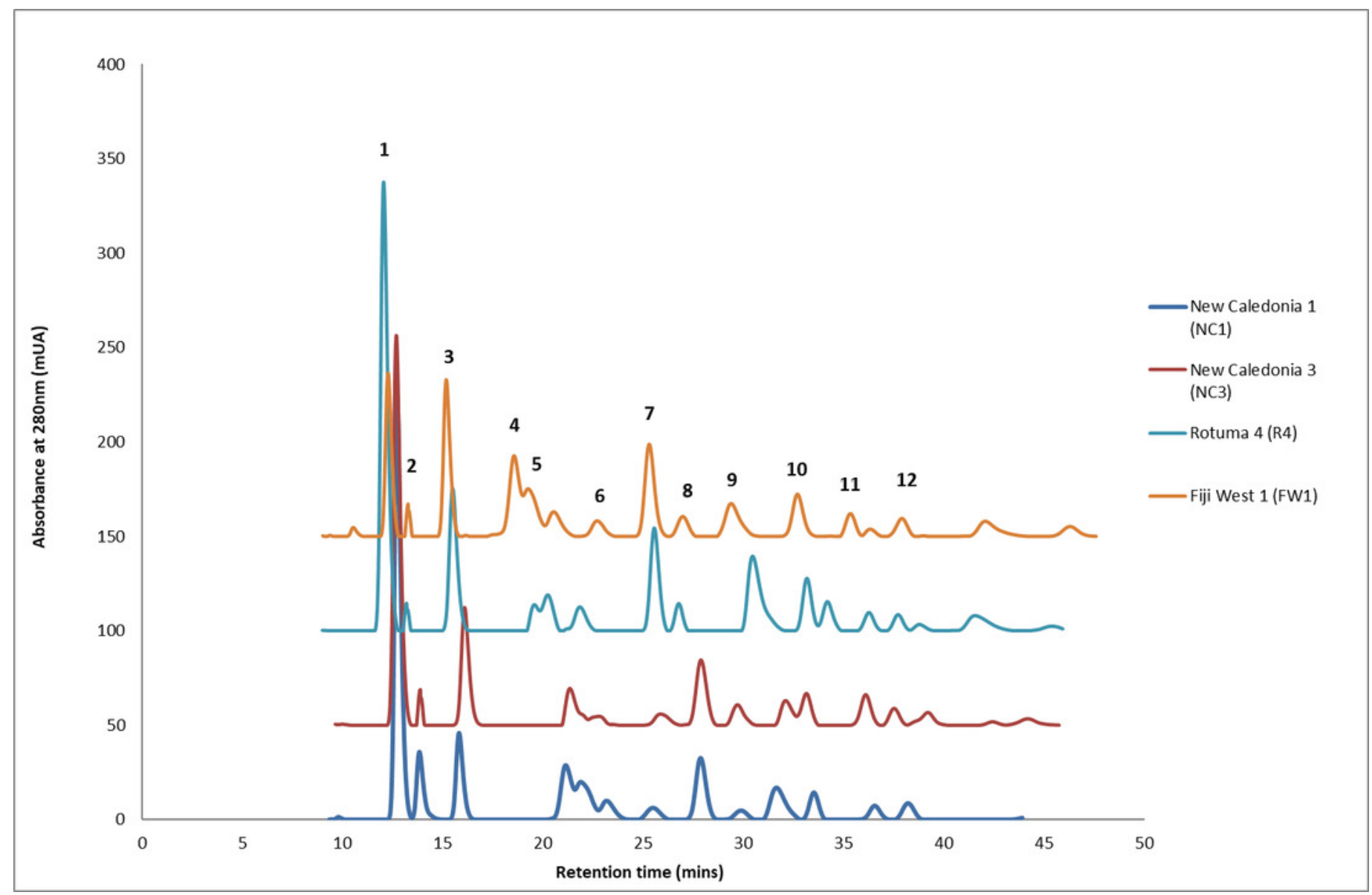


Figure 5 (on next page)

The PCA Scatter plot revealing the chemical diversity of $\mathrm{C}$. inophyllum within the three study areas.

The first two components correspond to $15.81 \%$ and $7.59 \%$ of the total variance respectively. Orange circles for Fiji, green squares for New Caledonia and blue diamonds for French Polynesia. 


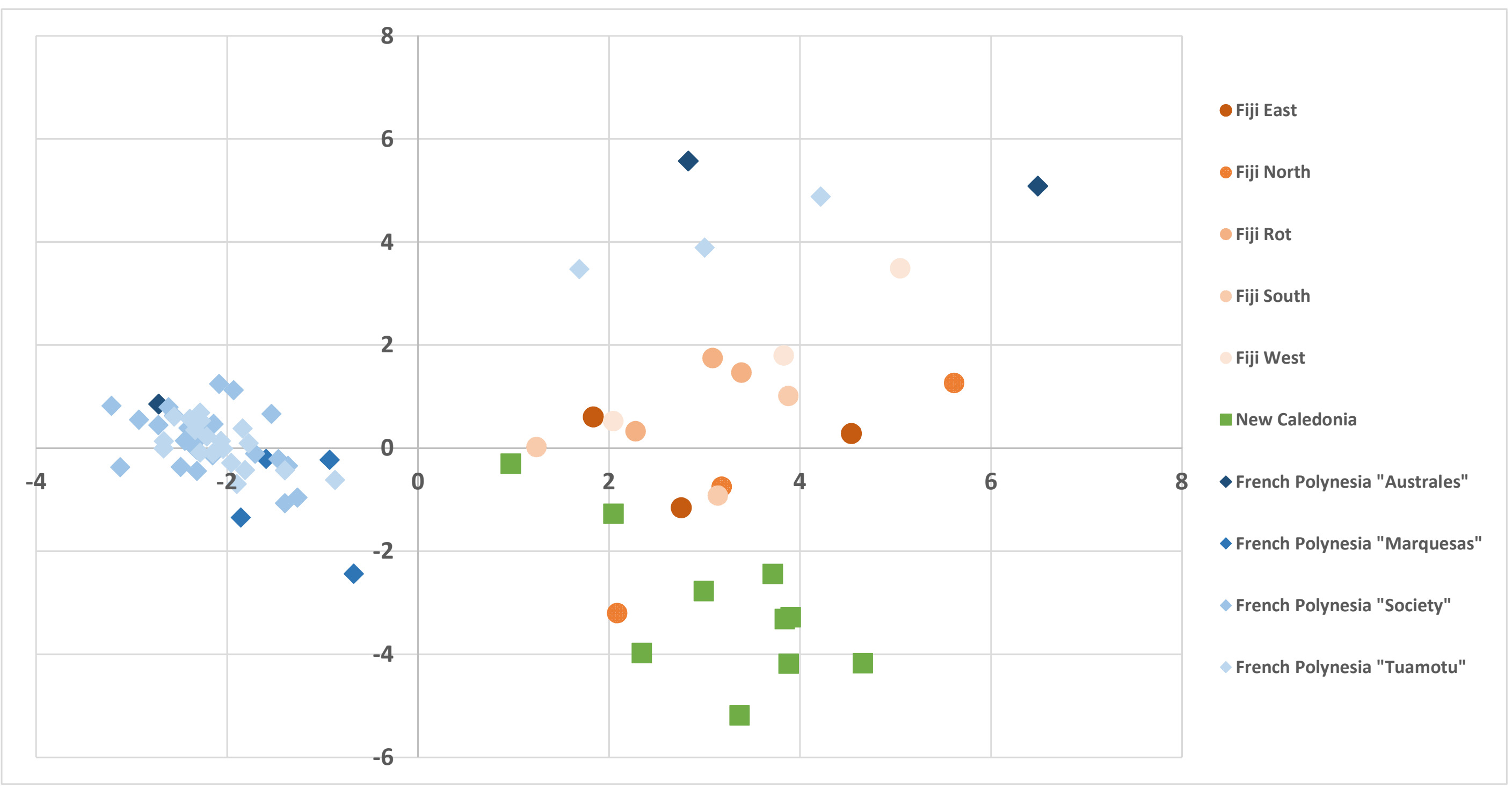


Figure 6

Variables factor map

PCA biplot generated using HPLC peak intensity variable's data. Uncharacterized compounds are mentioned Px.

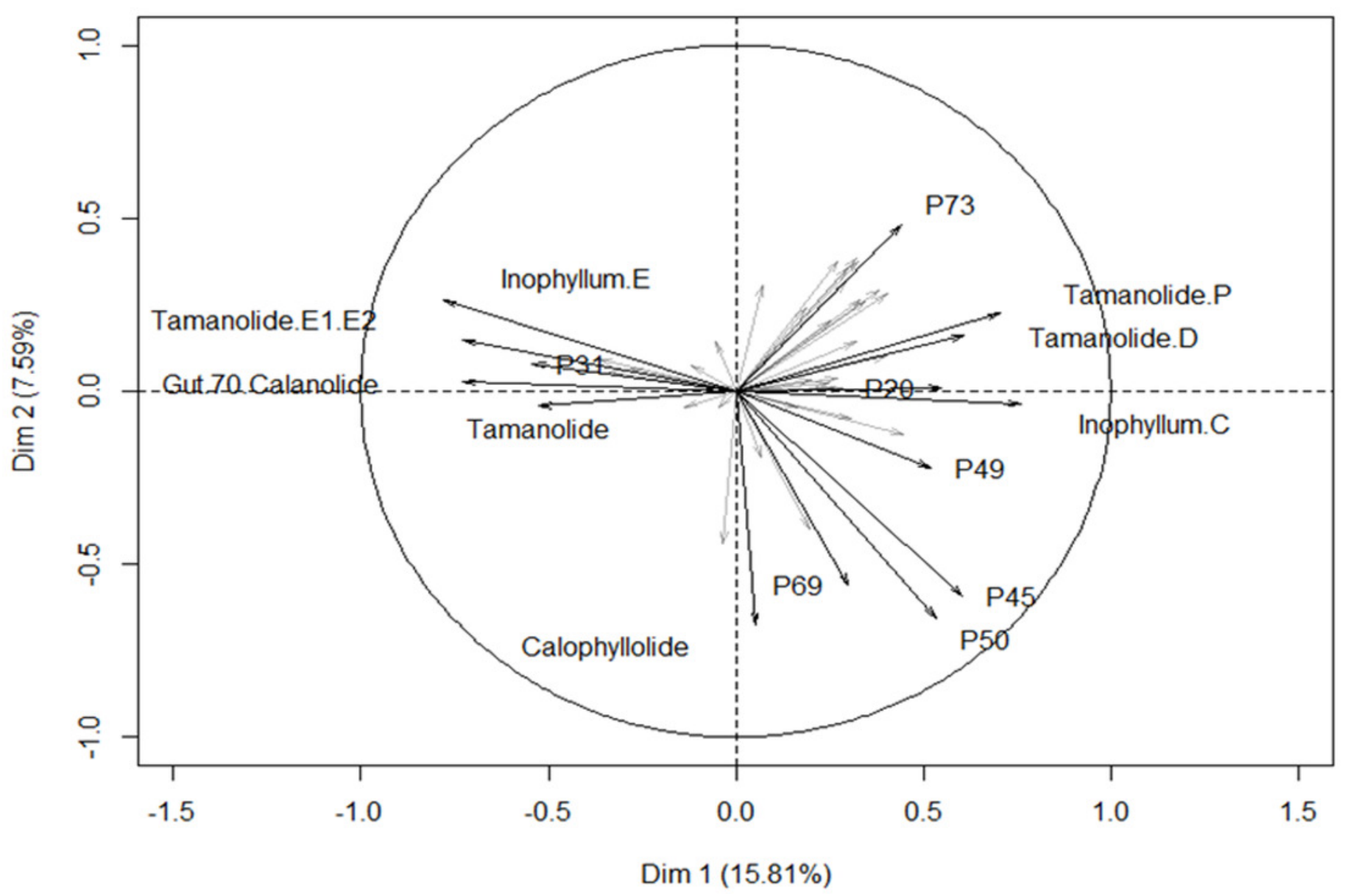




\section{Figure 7}

\section{Maximum likelihood trees for combined tamanu samples.}

(A) using the accD marker gene constructed using the Tamura 3 model and (B) depicts the Fiji (PsaA-Ycf3 spacer region) using the Tamura-Nei model. Both trees are supported by 500 bootstrap iterations. The scale represents the number of substitutions per site.

*Note: Auto Gamma Correction was used for the image. This only affects the reviewing manuscript. See original source image if needed for review.

A

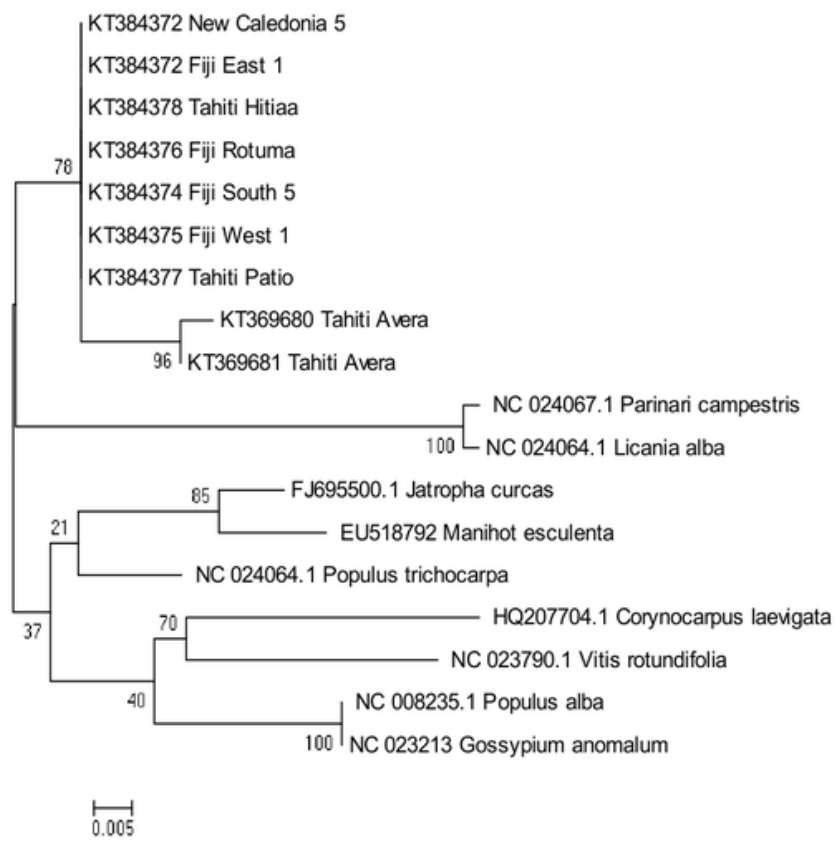

B

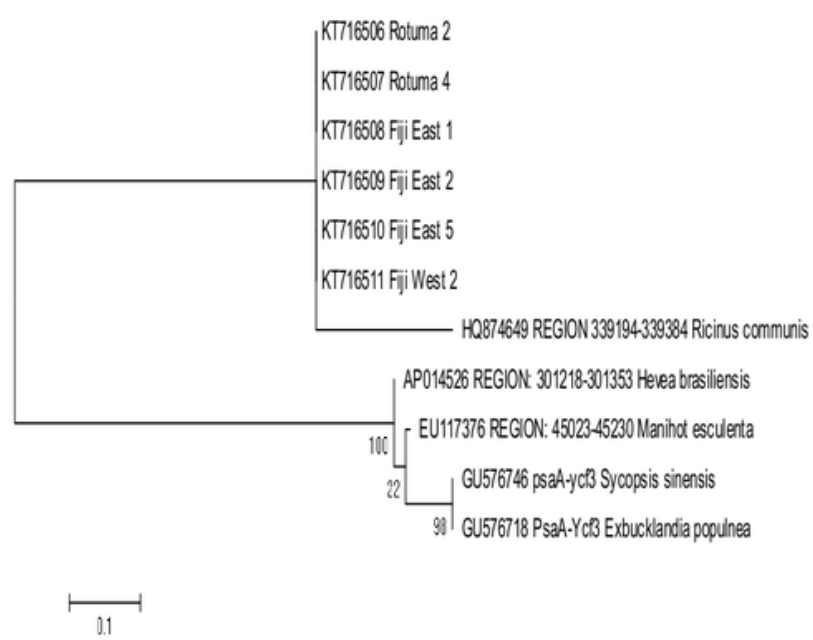




\section{Table $\mathbf{1}$ (on next page)}

Summary of Major Bioactive Compounds found in C. inophyllum resin oil with some bark and leaf constituents and their anti-cancer, anti-microbial, anti-HIV and antiinflammatory effects.

Compound References articles in parenthesis a. Patil et al., 1993 b. Itoigawa et al., 2001 c. Yimdjo et al., 2004 d. Kostova and Mojzis, 2007 e. Liang et al., 2006 f. Ishikawa, 2000 g. Saxena et al., 1982 h. Jin et al., 2011 


\begin{tabular}{|c|c|c|c|c|}
\hline Compounds & $\begin{array}{l}\text { Anti- } \\
\text { cancer }\end{array}$ & $\begin{array}{c}\text { Anti- } \\
\text { microbial }\end{array}$ & Anti-HIV & $\begin{array}{c}\text { Anti- } \\
\text { inflammatory }\end{array}$ \\
\hline Calophyllolide & $t^{b}$ & $t^{c}$ & & $t^{g}$ \\
\hline Inophyllum P & & & $t^{a, d}$ & \\
\hline Inophyllum C & $t^{b}$ & $t^{c}$ & $++^{a}$ & \\
\hline Inophyllum D & $t^{b}$ & & $t^{a}$ & \\
\hline Inophyllum E & $t^{b}$ & & & \\
\hline Inophyllum B & & & $t^{a, d}$ & \\
\hline Inophyllum A & $t^{b}$ & & $t^{a}$ & \\
\hline Calanolide Gut 70 & $t^{h}$ & & & \\
\hline Calanolide A /Calanolide B & & & $t^{d}$ & \\
\hline Calanolide/Pseudocalanolide D & & & $t^{f}$ & \\
\hline 12-Oxocalanolide & & & $t^{d, e}$ & \\
\hline
\end{tabular}

1 
Table 2 (on next page)

Sampling plan with GPS and DNA sample pretreatment for all samples 


\begin{tabular}{|c|c|c|c|c|c|c|c|}
\hline Country & Island & GPS Coor & inates & $\begin{array}{l}\text { Position / } \\
\text { (sample lal }\end{array}$ & $\begin{array}{l}\text { Village } \\
\text { bel) }\end{array}$ & Nuts & $\begin{array}{l}\text { Replicates } \\
\text { / site }\end{array}$ \\
\hline Fiji & Viti Levu & $\begin{array}{l}18^{\circ} 18^{\prime} 19^{\prime \prime} \mathrm{S} \\
18^{\circ} 18^{\prime} 52^{\prime \prime} \mathrm{S} \\
17^{\circ} 53^{\prime} 56^{\prime \prime} \mathrm{S} \\
17^{\circ} 38^{\prime} 30^{\prime \prime} \mathrm{S} \\
12^{\circ} 30^{\prime} 0^{\prime \prime S}\end{array}$ & $\begin{array}{l}178^{\circ} 33^{\prime} 38^{\prime \prime} \mathrm{E} \\
177^{\circ} 34^{\prime} 21^{\prime \prime} \mathrm{E} \\
178^{\circ} 44^{\prime} 44^{\prime \prime} \mathrm{E} \\
170^{\circ} 35^{\prime} 47^{\prime \prime} \mathrm{E} \\
177^{\circ} 4^{\prime} 59^{\prime \prime} \mathrm{E}\end{array}$ & $\begin{array}{l}\text { South (F-S1 } \\
\text { West (F-W } \\
\text { East (F-E1- } \\
\text { North (F-N } \\
\text { (R1-R5) }\end{array}$ & $\begin{array}{l}1-5) \\
1-5) \\
5) \\
1-5)\end{array}$ & $\begin{array}{l}5 \\
5 \\
5 \\
5 \\
5\end{array}$ & $\begin{array}{l}5 \\
5 \\
5 \\
5 \\
5\end{array}$ \\
\hline $\begin{array}{l}\text { New } \\
\text { Caledonia }\end{array}$ & Main land & $\begin{array}{l}22^{\circ} 18^{\prime} 05^{\prime \prime S} \\
22^{\circ} 09^{\prime} 03^{\prime \prime S}\end{array}$ & $\begin{array}{l}166^{\circ} 26^{\prime} 42^{\prime \prime E} \\
166^{\circ} 56^{\prime} 02^{\prime \prime E}\end{array}$ & $\begin{array}{l}\text { Nouméa } \\
\text { Yaté }\end{array}$ & $\begin{array}{l}\text { (N1-3) } \\
\text { (N4-6) }\end{array}$ & $\begin{array}{l}4 \\
5\end{array}$ & $\begin{array}{l}3 \\
3\end{array}$ \\
\hline $\begin{array}{l}\text { French } \\
\text { Polynesia }\end{array}$ & $\begin{array}{l}\text { Raiatea } \\
\text { Tahaa } \\
\text { Tahiti } \\
\text { Anaa } \\
\text { Apataki } \\
\text { Fakarava } \\
\text { Rangiroa } \\
\text { Raroia } \\
\text { Takapoto } \\
\text { Tikehau }\end{array}$ & 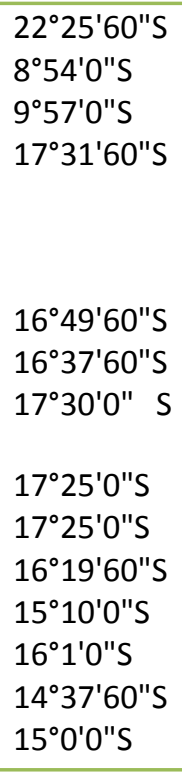 & $\begin{array}{r}151^{\circ} 25^{\prime} 1 " \mathrm{~W} \\
151^{\circ} 30^{\prime} 0^{\prime \prime} \mathrm{W} \\
149^{\circ} 30^{\prime} 0^{\prime \prime} \mathrm{W} \\
\\
145^{\circ} 30^{\prime} 0^{\prime \prime} \mathrm{W} \\
145^{\circ} 30^{\prime} 0^{\prime \prime} \mathrm{W} \\
145^{\circ} 37^{\prime} 1 " \mathrm{~W} \\
147^{\circ} 34^{\prime} 59^{\prime \prime} \mathrm{W} \\
142^{\circ} 27^{\prime} 0^{\prime \prime} \mathrm{W} \\
145^{\circ} 12^{\prime} 0^{\prime \prime} \mathrm{W} \\
148^{\circ} 10^{\prime} 1 " \mathrm{~W}\end{array}$ & $\begin{array}{l}\text { N.D. } \\
\text { Taiohae } \\
\text { Apatoni } \\
\text { Paopao } \\
\text { Haapiti } \\
\text { Taevaro } \\
\text { Opunohu } \\
\text { Avera } \\
\text { Patio } \\
\text { Hitiaa } \\
\text { Paea } \\
\text { N.D. } \\
\text { N.D. } \\
\text { Rotoava } \\
\text { Tiputa } \\
\text { Ouest } \\
\text { Fakatopate } \\
\text { Tuheraher }\end{array}$ & $\begin{array}{r}\text { (T1-T3) } \\
\text { (T4-T6) } \\
\text { (T7-T9) } \\
(\mathrm{T} 10-\mathrm{T} 12) \\
(\mathrm{T} 13-\mathrm{T} 15) \\
(\mathrm{T} 16-\mathrm{T} 18) \\
(\mathrm{T} 19-\mathrm{T} 21) \\
(\mathrm{T} 22-\mathrm{T} 24) \\
(\mathrm{T} 25-\mathrm{T} 27) \\
(\mathrm{T} 28-\mathrm{T} 30) \\
\text { (T31-T33) } \\
(\text { (T34-T36) } \\
\text { (T37-T39) } \\
\text { (T40-T42) } \\
\text { (T43-T45) } \\
\text { (T46-T48) } \\
\text { r (T49-51) } \\
\text { (T52-54) }\end{array}$ & $\begin{array}{l}3 \\
1 \\
3 \\
3 \\
1 \\
1 \\
1 \\
3 \\
3 \\
3 \\
3 \\
2 \\
2 \\
3 \\
7 \\
3 \\
3 \\
2\end{array}$ & $\begin{array}{l}3 \\
3 \\
3 \\
3 \\
3 \\
3 \\
3 \\
3 \\
3 \\
3 \\
3 \\
3 \\
3 \\
3 \\
3 \\
3 \\
3 \\
3\end{array}$ \\
\hline
\end{tabular}

1 


\section{Table 3 (on next page)}

NMR data for tamanolide E1, tamanolide E2, calanolide D, inophyllum E at $500 \mathrm{MHz}$ $\left(\mathrm{CDCl}_{3}, 300 \mathrm{~K}\right)$

$\delta$ in ppm, $\left({ }^{13} \mathrm{C}\right.$ multiplicity determinate by ${ }^{13} \mathrm{C}$-DEPTQ135 and HSQCed), (br: broad, s : singlet ;

$\mathrm{d}$ : doublet ; $\mathrm{t}$ : triplet ; $q$ :quadruplet ; sxt ; sextuplet ; $\mathrm{m}$ : multiplet ; J Hz) 


\begin{tabular}{|c|c|c|c|c|c|c|}
\hline \multirow[t]{2}{*}{ atom } & \multicolumn{2}{|c|}{$\begin{array}{c}\text { Tamanolide-E1 } \\
\text { (diast-1/2 } \underline{70} / 30)\end{array}$} & \multicolumn{2}{|c|}{$\begin{array}{c}\text { Tamanolide-E2 } \\
\text { (diast } 1 / \underline{2} \text { 40/60) }\end{array}$} & \multirow[t]{2}{*}{ Tamanolide D } & \multirow{2}{*}{$\begin{array}{l}\text { Inophyllum-E } \\
\delta_{1 \mathrm{H}}\end{array}$} \\
\hline & $\delta_{13 c}$ & $\delta_{1 \mathrm{H}}$ & $\delta_{13 c}$ & $\delta_{1 \mathrm{H}}$ & & \\
\hline 2 & $160.4(C)$ & - & $160.4(C)$ & - & - & - \\
\hline 3 & $109.3(\mathrm{CH})$ & 6.16 (brs) & $109.3(\mathrm{CH})$ & 6.16 (brs) & 6.08 (brs) & $6.05(\mathrm{~s})$ \\
\hline 4 & $163.0(C)$ & - & $163.0(C)$ & - & - & - \\
\hline $4 a$ & $104.7(C)$ & - & $104.7(C)$ & - & - & - \\
\hline $4 b$ & $156.2(\mathrm{C})$ & - & $156.2(\mathrm{C})$ & - & - & - \\
\hline 6 & $79.4(C)$ & - & $79.4(C)$ & - & - & - \\
\hline 7 & $127.2(\mathrm{CH})$ & $5.60(d, 10.0)$ & $127.2(\mathrm{CH})$ & $5.60(d, 10.0)$ & $5.54(d, 10.0)$ & $5.41(d, 10.0)$ \\
\hline 8 & $116.1(\mathrm{CH})$ & $6.66(d, 10.0)$ & $116.1(\mathrm{CH})$ & $6.66(d, 10.0)$ & $6.66(d, 10.0)$ & $6.55(\mathrm{~d}, 10.0)$ \\
\hline $8 a$ & 105.9 (C) & - & $105.9(\mathrm{C})$ & - & - & - \\
\hline $8 b$ & $158.9(\mathrm{C})$ & - & $158.9(\mathrm{C})$ & - & - & - \\
\hline 10 & $77.4(\mathrm{CH})$ & 4.69 (qd, 6.6, 3.4) & $77.4(\mathrm{CH})$ & $4.70(q d, 6.6,3.4)$ & $4.51(q d, 6.6,1.8)$ & $4.72(q d, 6.6,3.4)$ \\
\hline 11 & $46.2(\mathrm{CH})$ & $2.68(q d, 7.2,3.4)$ & $46.1(\mathrm{CH})$ & $2.69(q d, 7.2,3.4)$ & 2.03 (qdd, $7.2,2.1 ; 1.8)$ & $2.71(q d, 7.2,3.4)$ \\
\hline 12 & $191.7(C)$ & - & $191.6(C)$ & - & - & - \\
\hline $12 a$ & $103.2(\mathrm{C})$ & - & $103.2(\mathrm{C})$ & - & - & - \\
\hline $12 b$ & 155.9 (C) & - & 155.9 (C) & - & - & - \\
\hline 13 & $37.5(\mathrm{CH})$ & 3.79 (brsxt, 7.0) & $37.5(\mathrm{CH})$ & 3.79 (brsxt, 7.0) & 3.86 (brsxt; 6.6) & - \\
\hline 14 & $29.5\left(\mathrm{CH}_{2}\right)$ & $\begin{array}{l}1.75(\mathrm{~m}) \\
1.45(\mathrm{~m})\end{array}$ & $29.6\left(\mathrm{CH}_{2}\right)$ & $\begin{array}{l}1.75(\mathrm{~m}) \\
1.45(\mathrm{~m})\end{array}$ & $\begin{array}{l}1.78(\mathrm{~m}) \\
1.46(\mathrm{~m})\end{array}$ & $7.37(\mathrm{~m})$ \\
\hline 15 & $12.0\left(\mathrm{CH}_{3}\right)$ & $0.95(t, 7.4)$ & $12.0\left(\mathrm{CH}_{3}\right)$ & $0.96(t, 7.4)$ & $0.97(t, 7.3)$ & $7.22(\mathrm{~m})$ \\
\hline 16 & $20.1\left(\mathrm{CH}_{3}\right)$ & $1.22(d, 6.7)$ & $20.0\left(\mathrm{CH}_{3}\right)$ & $1.22(d, 6.7)$ & $1.22(d, 6.9)$ & $7.37(\mathrm{~m})$ \\
\hline 17 & - & - & - & - & - & $7.22(\mathrm{~m})$ \\
\hline 18 & - & - & - & - & - & $7.37(\mathrm{~m})$ \\
\hline 19 & $28.3\left(\mathrm{CH}_{3}\right)$ & $1.54(\mathrm{~s})$ & $28.3\left(\mathrm{CH}_{3}\right)$ & $1.53(\mathrm{~s})$ & $1.48(\mathrm{~s})$ & $0.97(\mathrm{~s})$ \\
\hline 20 & $28.2\left(\mathrm{CH}_{3}\right)$ & $1.53(\mathrm{~s})$ & $28.2\left(\mathrm{CH}_{3}\right)$ & $1.53(\mathrm{~s})$ & $1.49(\mathrm{~s})$ & $0.95(\mathrm{~s})$ \\
\hline 21 & $16.2\left(\mathrm{CH}_{3}\right)$ & $1.42(d, 6.6)$ & $16.2\left(\mathrm{CH}_{3}\right)$ & $1.41(d, 6.6)$ & $1.43(d, 6.6)$ & $1.42(d, 6.6)$ \\
\hline 22 & $9.4\left(\mathrm{CH}_{3}\right)$ & $1.15(d, 7.2)$ & $9.4\left(\mathrm{CH}_{3}\right)$ & $1.15(d, 7.2)$ & $0.80(d, 7.2)$ & $1.18(d, 7.3)$ \\
\hline
\end{tabular}

